\title{
OBITUARY
}

\section{Dr. W. John Long}

He was born in Bendigo, Victoria, Australia on 12th May, 1906, and educated at Scotch College, Melbourne where he won trophies for swimming and diving. He studied medicine at University of Melbourne, played water polo for University and was breakaway for the Rugby Club. Later he played in combined Australian Universities Rugby team and was awarded a Full Blue in this sport.

After spending a year in Adelaide as a resident, he returned to Bendigo to join his father W. J. Long, Sr. in general surgical practice in the early 1930's. He served several generations in the community by continuing to practice there and in Bendigo Base Hospital until April, 1984. Serving in capacities over the years as Honorary Surgeon and then Honorary Obstetrician and Gynaecologist. He always kept up to date and was known for his deft skills and nimble hands in this latter capacity until his cessation of practice. He remained on the Board of the Hospital for many years until a few months before his death. His practice in Bendigo was only broken by two years during the war during which time he served in the Medical Corps of the Australian Army.

His association with sports continued throughout his life, both as a participant and via sports associations and sports medicine. A long time member of the Bendigo Golf Club, he spent several years as President (as had his father before him) and actively played, last winning a tournament earlier this year.

In the 1950's he raced homing pigeons and was President of the Club for several years. Later, he showed pigeons and won many ribbons in Agricultural Shows.

He was an accomplished marksman, shooting with the South Bendigo Rifle Club and later with the Small Bore Club. In the last year or two, he found that increasing deafness left him with little time when shooting quail or ducks.

In his earlier years in Bendigo he swam and played water polo at Bendigo Swimming Club. He maintained an active interest in cricket and football and was a member and regular attender of the MCC (Melbourne Cricket Club) for over $\mathbf{5 0}$ years. He was honorary surgeon of the Bendigo Jockey Club until his death.

Not having seen snow of any significance until a few years ago, he did not have the opportunity to partake of the related winter sports until recently, at the age of 75 , he learned to ski cross country in Canada where he became reasonably able at the art.

He was a member of the Sportsmen's Association of Australia from near its inception until his death.

He was predeceased by his wife and second son, leaving five children and twelve grandchildren.

W. John Long III

I feel John's death as a personal loss. Although our earlier contact had only been on such matters as subscription reminders and answers to queries, after the World Congress of Sports Medicine held in Melbourne in 1974, he collected my wife and myself from the Conference Hall and took us out many miles to the old gold-mining town of Bendigo, treating us with kindness and generosity, taking us round the area, and giving an insight into Australian medicine and life there in general. I, and our association, have lost a good friend.

H. E. Robson 